\title{
Investigation on Compressive Formability and Microstructure Evolution of 6082-T6 Aluminum Alloy
}

\author{
Zhouli Xu ${ }^{1,2}$, Huijuan Ma ${ }^{1,3} \mathbb{D}$, Ning Zhao ${ }^{1,3}$ and Zhili $\mathrm{Hu}^{1,3,4, *}$ \\ 1 Hubei Key Laboratory of Advanced Technology for Automotive Components, Wuhan University of \\ Technology, Wuhan 430070, China; whutxuzhouli@whut.edu.cn (Z.X.); mahuijuan21@whut.edu.cn (H.M.); \\ zhao_ning@whut.edu.cn (N.Z.) \\ 2 School of Materials Science and Engineering, Wuhan University of Technology, Wuhan 430070 China \\ 3 Hubei Collaborative Innovation Center for Automotive Components Technology, Wuhan University of \\ Technology, Wuhan 430070, China \\ 4 Hubei Engineering Research Center for Green \& Precision Material Forming, Wuhan University of \\ Technology, Wuhan 430070, China \\ * Correspondence: zhilihuhit@163.com; Tel.: +1-027-8785-6733
}

Received: 24 February 2020; Accepted: 26 March 2020; Published: 3 April 2020

\begin{abstract}
The 6xxx aluminum alloy is the first choice for automotive lightweight forgings due to its excellent performance, high strength and low weight. The production time of current aluminum alloy forging generally exceeds $10 \mathrm{~h}$. To reduce the production time of traditional aluminum alloy forgings, 6082-T6 aluminum alloy is used in the forming process. The effects of different heating temperatures $\left(200{ }^{\circ} \mathrm{C}, 300{ }^{\circ} \mathrm{C}\right.$, and $400{ }^{\circ} \mathrm{C}$ ) and deformation degrees $(30 \%, 50 \%$, and $70 \%)$ on the deformability and properties of 6082-T6 billets have been investigated. The results show that when the heating temperature is higher than $300{ }^{\circ} \mathrm{C}$, the compressive deformation resistance obviously decreases with increasing strength. With compression at $200{ }^{\circ} \mathrm{C}$ and $70 \%$ deformation with short heating time, the strength of the sample is close to the T6 (solution treatment and artificial aging) state. A large number of dislocations and subgrains were introduced due to the compression deformation, and their amounts decreased as the heating temperature increased. The size of the precipitated phase $\beta^{\prime \prime}$ slightly grows under a heating temperature of $200^{\circ} \mathrm{C}$. However, when the heating temperature is higher than $300^{\circ} \mathrm{C}$, the precipitated phase gradually changes from $\beta^{\prime \prime}$, which is optimal for the strengthening effect, to $\beta^{\prime}$ and $\beta$, which offer weaker strengthening. Therefore, under a lower heating temperature of $200^{\circ} \mathrm{C}$ for $5 \mathrm{~min}$, a large number of dislocations are introduced with the $\beta^{\prime \prime}$ precipitated phase, leading to higher strength with less heat treatment time.
\end{abstract}

Keywords: 6082-T6 aluminum alloy; compressive deformation; mechanical properties; precipitated phase; dislocation

\section{Introduction}

In recent years, with increasingly stringent regulations on energy and emissions reduction, lightweight technology in the automobile industry has received extensive attention and research. The 6082 aluminum alloy, which has the advantages of high strength, high surface finish, and less processing, has become the preferred material for lightweight automotive forgings [1]. However, the traditional process of aluminum alloy forming is complex. Many scholars have engaged in numerous studies to minimize the processing time, reduce energy consumption, and ensure that the product has good mechanical properties [2]. Huo et al. [3] investigated the warm-forming properties of 7075-T6 sheets. The properties and precipitates after forming at different temperatures were studied, revealing that the inherent high strength of the T6 blank was perfectly preserved after $200{ }^{\circ} \mathrm{C}$. Ehab et al. [4] 
studied the effect of temperature on the forming properties of 6082-T4 aluminum alloy. Under different heating temperatures, there were considerable differences in the mechanical properties. Zhang et al. [5] studied the compressive stress state of 6082 aluminum alloy in a T4 and annealed state and analyzed the softening phenomenon under different heating temperatures and strain rates. Birol et al. investigated the influence of the preparation method of 6082 aluminum alloy billets on forging products. When a 6082 aluminum alloy billet produced by casting is used, the grain structure of the product after forging is fine-grained and uniform. At the same time, the blank was heated and forged into a shape, and a quenching process was performed. In this process, the blank was directly aged without solution treatment, and products with good mechanical properties and grain structure were obtained [6,7]. Bouquerel et al. [8] investigated the microstructure change of 6082 aluminum alloy before and after cold forming. Garrett et al. [9] studied the effects of solution time and deformation rate on the flow stress, ductility, and anisotropy of a 6082 aluminum alloy. Dadbakhsh et al. [10] strengthened a commercial $6082 \mathrm{Al}$ alloy by using equal channel angular pressing (ECAP). An increase in both strength and ductility of the ECAPed specimen was achieved. Cabibbo [11] studied microstructure strengthening mechanisms in different equal channel angular pressed aluminum alloys.

There is little research on the forging abilities and post-forging performance of aluminum alloys with T6 states. Normally, aluminum alloy billet used for forging is applied in soft conditions (O or F temper), and after forging, the formed part develops the hardened conditions (T6 tempers) by solution and artificial aging treatment. It is well known that the solution and artificial aging treatment for the parts takes more than $10 \mathrm{~h}$, which makes the traditional forming production of aluminum alloy time-consuming and labor-intensive. A new forging process is designed as follows: Forging billet (T6 temper)—-heating-forging-edge cutting after cooling. The T6 treatment aluminum alloy is directly used as the billet and no heat treatment is required after forging. The billet with T6 temper is rapidly formed at a suitable temperature to ensure that the part has good thermoplastic processing properties and high mechanical properties after deformation. This method significantly reduces the production time during forging and reduces equipment expenses for post-forging heat treatment (shown in Figure 1).

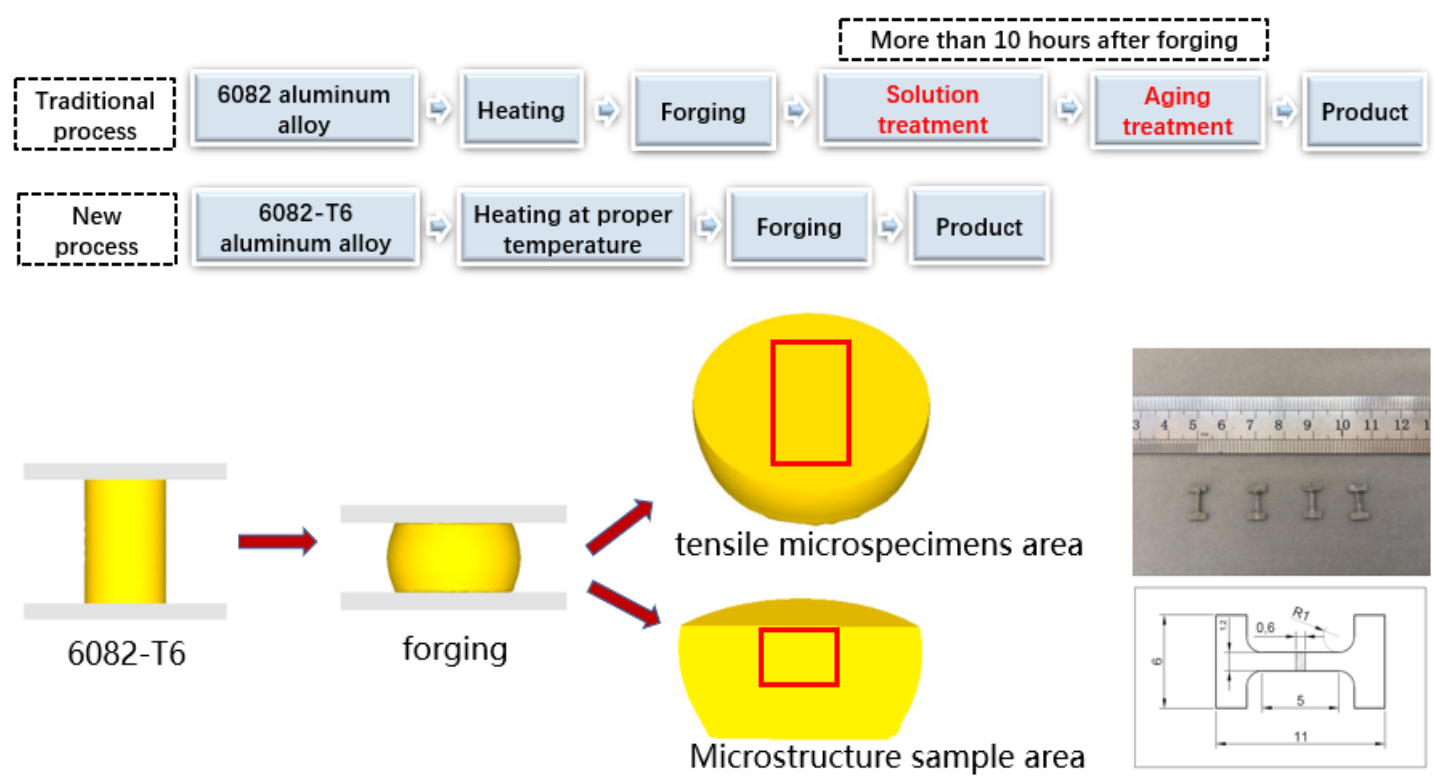

Figure 1. Experimental process and sampling area.

In this paper, the formability of a 6082-T6 alloy at temperatures ranging from $200{ }^{\circ} \mathrm{C}$ to $400{ }^{\circ} \mathrm{C}$ and compression degrees ranging from $30 \%$ to $70 \%$ is investigated. The microstructure evolution of 6082-T6 after forming is also studied. A proper temperature range is determined that enhanced forging ability and maintained high strength after forging. 


\section{Materials and Experimental Methods}

A 6082 aluminum alloy with chemical composition of Si $0.95 \mathrm{wt} \%$-Fe $0.18 \mathrm{wt} \%$-Cu $0.06 \mathrm{wt} \%-\mathrm{Mn}$ $0.45 \mathrm{wt} \%-\mathrm{Mg} 0.65 \mathrm{wt} \%-\mathrm{Cr} 0.12 \mathrm{wt} \%-\mathrm{Zn} 0.005 \mathrm{wt} \%$-Ti $0.1 \mathrm{wt} \%$ and $\mathrm{Al}$ balanced was produced by casting and extrusion process. Small cylindrical specimens with $10 \mathrm{~mm}$ in diameter and $15 \mathrm{~mm}$ in height were cut from the extruded rods using an electric discharge machining wire cutter. The cylindrical specimens were T6-treated (solution treatment at $530{ }^{\circ} \mathrm{C}$ for $2 \mathrm{~h} \rightarrow$ quenched to room temperature (RT) in water $\rightarrow$ aged at $180^{\circ} \mathrm{C}$ for $8 \mathrm{~h}$ ).

The T6-treated cylindrical specimens were subjected to a hot compression test on a Gleeble 3500 (DATA SCIENCES INTERNATIONAL Inc., St. Pau, MN, USA) testing machine. To improve the formability, the sample was rapidly heated to the specified temperature using a thermocouple with a heating rate of $5^{\circ} \mathrm{C} / \mathrm{s}$, and a compression test was performed after $5 \mathrm{~min}$ of incubation at the test temperature. The compression strain rate was $1 \mathrm{~s}^{-1}$. After completing the compression test, the sample was quenched to room temperature in water immediately. Three groups of different temperatures $\left(200{ }^{\circ} \mathrm{C}, 300{ }^{\circ} \mathrm{C}\right.$, and $\left.400{ }^{\circ} \mathrm{C}\right)$ and three groups of different compression degrees $(30 \%, 50 \%$, and $70 \%)$ were combined into 9 groups of variables. To evaluate the post-forming mechanical properties of the samples, tensile microspecimens were taken from the samples using an electric discharge machining wire cutter, as shown in Figure 1.

Samples machined from the specimen at different test temperatures were used to investigate the microstructure (Figure 1). The microstructures of the samples were characterized by transmission electron microscopy (TEM) and scanning electron microscopy (SEM). A FEIQUANTA 450 SEM (FEI Inc., Hillsboro, OR, USA) was used for electron backscattered diffraction (EBSD) analysis and observed precipitated phase distribution. Thin foils for TEM observation were mechanically thinned down to $0.1 \mathrm{~mm}$ thickness and then were twin-jet electropolished at $-23{ }^{\circ} \mathrm{C}$ in a solution consisting of $30 \%$ $\mathrm{HNO}_{3}$ and $70 \% \mathrm{CH}_{3} \mathrm{OH}$. TEM examinations were performed on a JEM-1400Plus (JEOL, Tokyo, Japan).

\section{Experimental Results}

\subsection{Compression Behavior of 6082-T6}

Figure 2 shows the true strain-stress curves of 6082-T6 under different compression degrees $(30 \%$, $50 \%$, and $70 \%$ ) and temperatures $\left(200{ }^{\circ} \mathrm{C}, 300^{\circ} \mathrm{C}\right.$, and $\left.400{ }^{\circ} \mathrm{C}\right)$. In different compression conditions, as the strain increased, the stress value rose rapidly, and the work hardening rate $(\delta / \varepsilon \delta$ : stress, $\varepsilon$ : strain) was consistent at low strain. When the stress reached a certain value, the deformation resistance no longer increased with the increase of the strain, and showed a state of steep rising then stabilizing on the compression curve. The maximum true stress required for compression increased as the heating temperature increased. The compression degree had little effect on the compressive strength. At the same temperature, the compressive strengths obtained by different compression degrees were similar. The compressive strength of the samples at temperatures of $200^{\circ} \mathrm{C}, 300^{\circ} \mathrm{C}$, and $400{ }^{\circ} \mathrm{C}$ were between $245 \mathrm{MPa}$ and $275 \mathrm{MPa}$, between $130 \mathrm{MPa}$ and $145 \mathrm{MPa}$, and between $50 \mathrm{MPa}$ and $55 \mathrm{MPa}$, respectively.
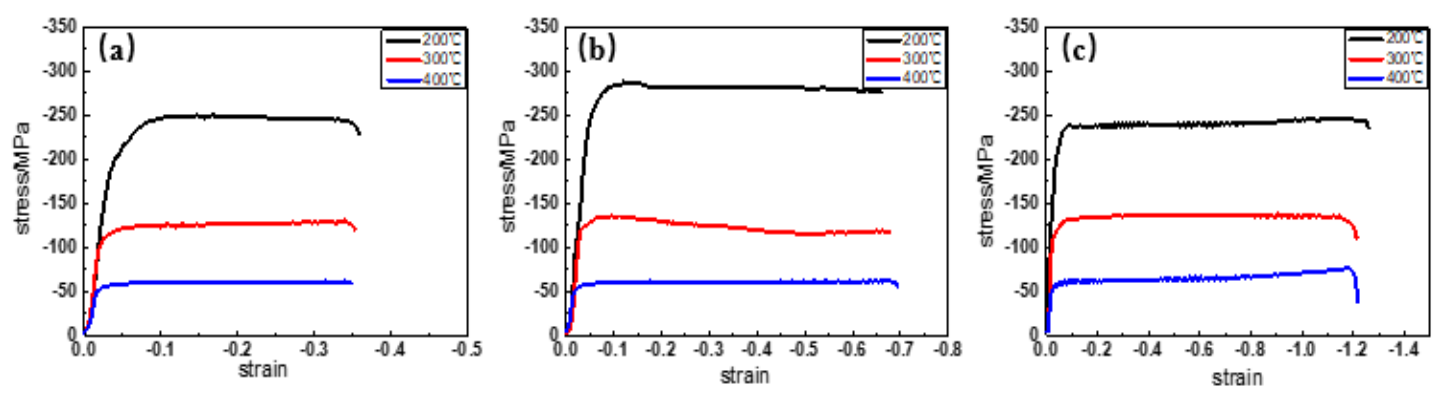

Figure 2. 6082-T6 compression true stress-strain curves (a) 30\%; (b) 50\%; (c) 70\%. 


\subsection{Post-Forming Mechanical Properties}

Figure $3 a-c$ shows the true strain-stress curves of post-forming samples under different conditions. The tensile strength of the 6082-T6 billet was approximately $315 \mathrm{MPa}$, and the elongation was $9.5 \%$. When the heating temperature was $200{ }^{\circ} \mathrm{C}$, the tensile strength (UTS) corresponding to compressions of $30 \%, 50 \%$, and $70 \%$ was $291 \mathrm{MPa}, 280 \mathrm{MPa}$, and $301 \mathrm{MPa}$, respectively. Detailed data are shown in Figure 3d,e. Different compression degrees (30\%, 50\%, and 70\%) affected the tensile strength in $200{ }^{\circ} \mathrm{C}$. When the heating temperature increased from $200{ }^{\circ} \mathrm{C}$ to $300{ }^{\circ} \mathrm{C}$, the UTS of the specimens obviously decreased, as for the range from $300^{\circ} \mathrm{C}$ to $400{ }^{\circ} \mathrm{C}$. This reduction is not as obvious as the previous case. As is clear from these figures, compression degree has little effect on tensile strength in temperatures $300{ }^{\circ} \mathrm{C}$ and $400{ }^{\circ} \mathrm{C}$. After compression deformation at higher temperatures, the specimen showed good elongation. After compression in different temperatures $200{ }^{\circ} \mathrm{C}, 300{ }^{\circ} \mathrm{C}$, and $400{ }^{\circ} \mathrm{C}$, the true total elongations were between $11 \%$ and $12 \%$, between $15 \%$ and $17 \%$, and between $21 \%$ and $24 \%$, respectively (Figure 3e). Similarly, there was no obvious effect of different deformation degrees on the increase of true total elongation at the same temperature.
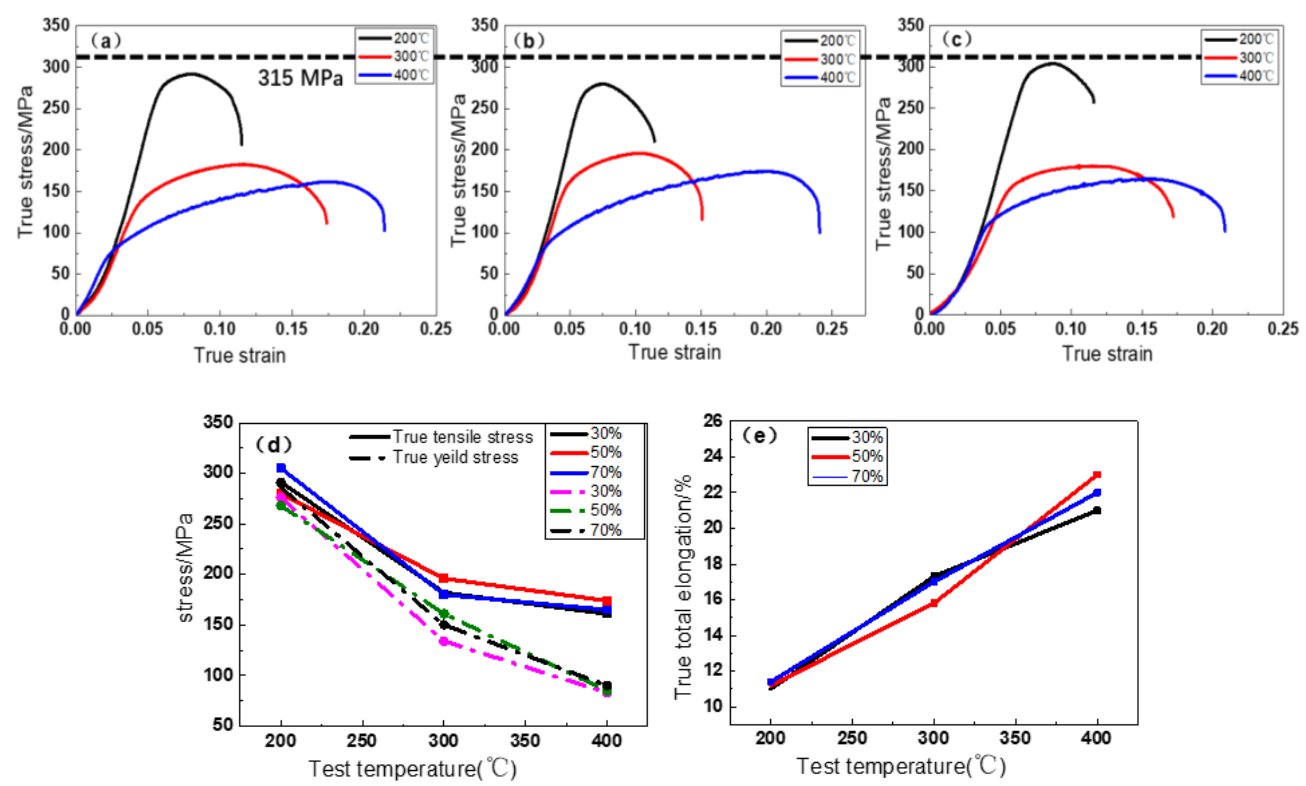

Figure 3. Tensile true stress-strain curves of samples with different deformation degrees: (a) 30\%; (b) $50 \%$; (c) $70 \%$; (d) true tensile/yield stress; (e) true total elongation.

\subsection{Microstructural Evolution}

The heating temperature had a great influence on the properties after forming, while the degree of deformation under the same heating temperature had little effect. Therefore, samples with different heating temperatures of $50 \%$ compression degree were selected to investigate the microstructural evolution. Figure 4 shows the electron backscattered diffraction (EBSD) images of the original 6082-T6 sample and the post-forming samples with a deformation degree of $50 \%$. Figure 4 a shows the grain size of the undeformed T6 sample. The overall grain size was large and shows long strips due to an extruded 6082 billet. The average grain thickness was approximately $80-100 \mu \mathrm{m}$, and a few small grains were evident at the edge of large grains. After forming at $200{ }^{\circ} \mathrm{C}$, a large number of small grains were introduced. Figure 5 shows a grain boundary misorientation angle map under the field of view in Figure 4. The T6 sample (Figure 5a) had a small number of small angle grain boundaries. Compared with the unformed 6082-T6 sample, compression introduced a large number of small angle grain boundaries of $2-15^{\circ}$ grain boundaries (often considered subgrains and dislocations). The dynamic recovery and recrystallization were incomplete during compression, and a large number of dislocations and subgrains have been preserved. 

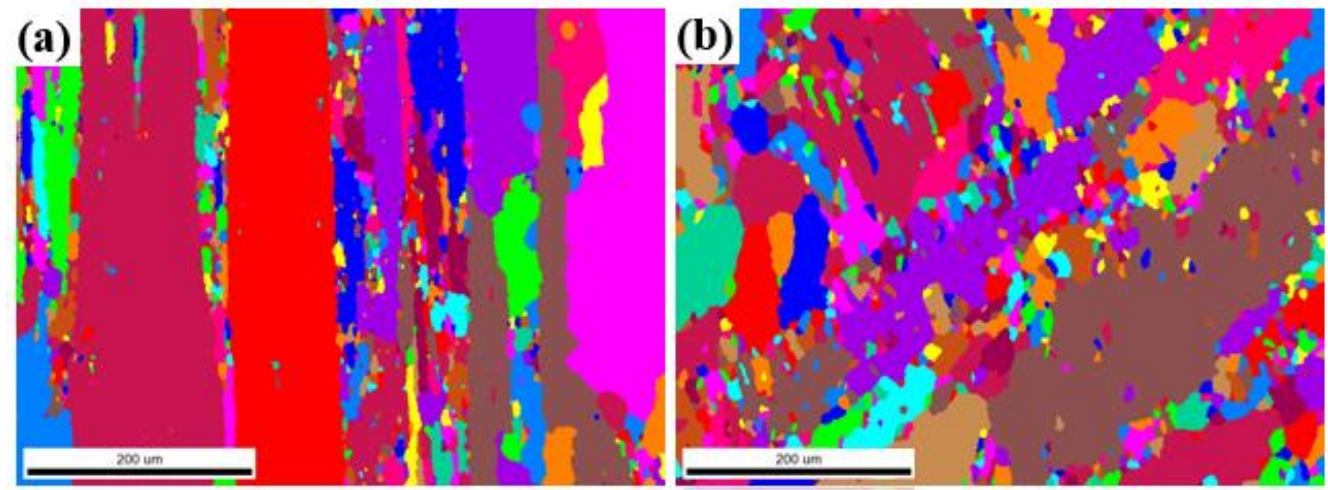

Figure 4. Electron backscattered diffraction (EBSD) micrographs of (a) T6; (b) $200{ }^{\circ} \mathrm{C}$ under $50 \%$ compression.
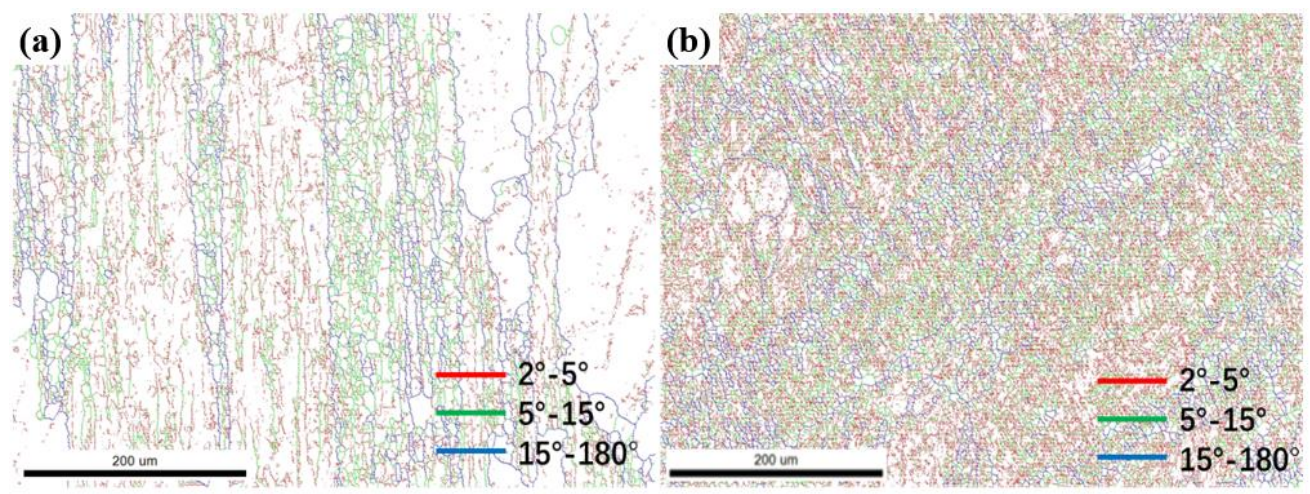

Figure 5. Small angle grain boundary maps (a) T6; (b) $200^{\circ} \mathrm{C}$.

Figure 6 shows SEM dark field images of $6082-\mathrm{T} 6$ and post-forming samples with $50 \%$ at $200{ }^{\circ} \mathrm{C}$, $300{ }^{\circ} \mathrm{C}$, and $400{ }^{\circ} \mathrm{C}$. The white spots in the figures are the precipitated phases and insoluble phases, which are different from the aluminum matrix component. As shown in Figure 6a, the white spots in the picture vary in size. According to the EDS analysis of the point indicated by the red cross in Figure 6a, the main components of the large-size phase are Mn and Fe. They are usually considered to be intermetallic phases and insoluble phases. The small white points in the picture are the precipitated phases with a strengthening effect. Figure $6 \mathrm{~b}$ shows that the number of precipitated phases of the 6082-T6 aluminum alloy is large and uniformly distributed. After deformation, the number of precipitated phases decreased gradually as the temperature increased. Other experimental results, such as precipitated phase morphology and dislocation density, need to be further observed and confirmed by TEM.
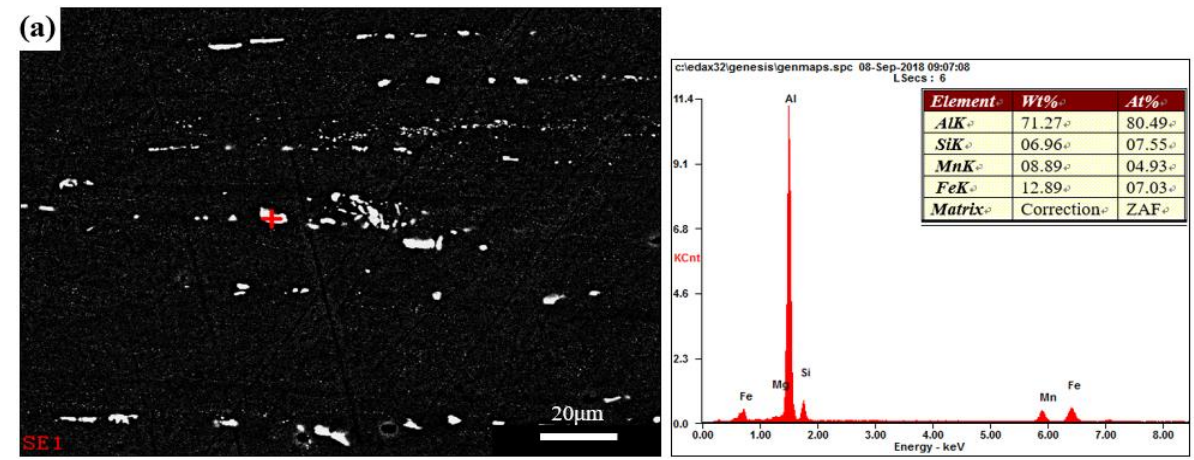

Figure 6. Cont. 

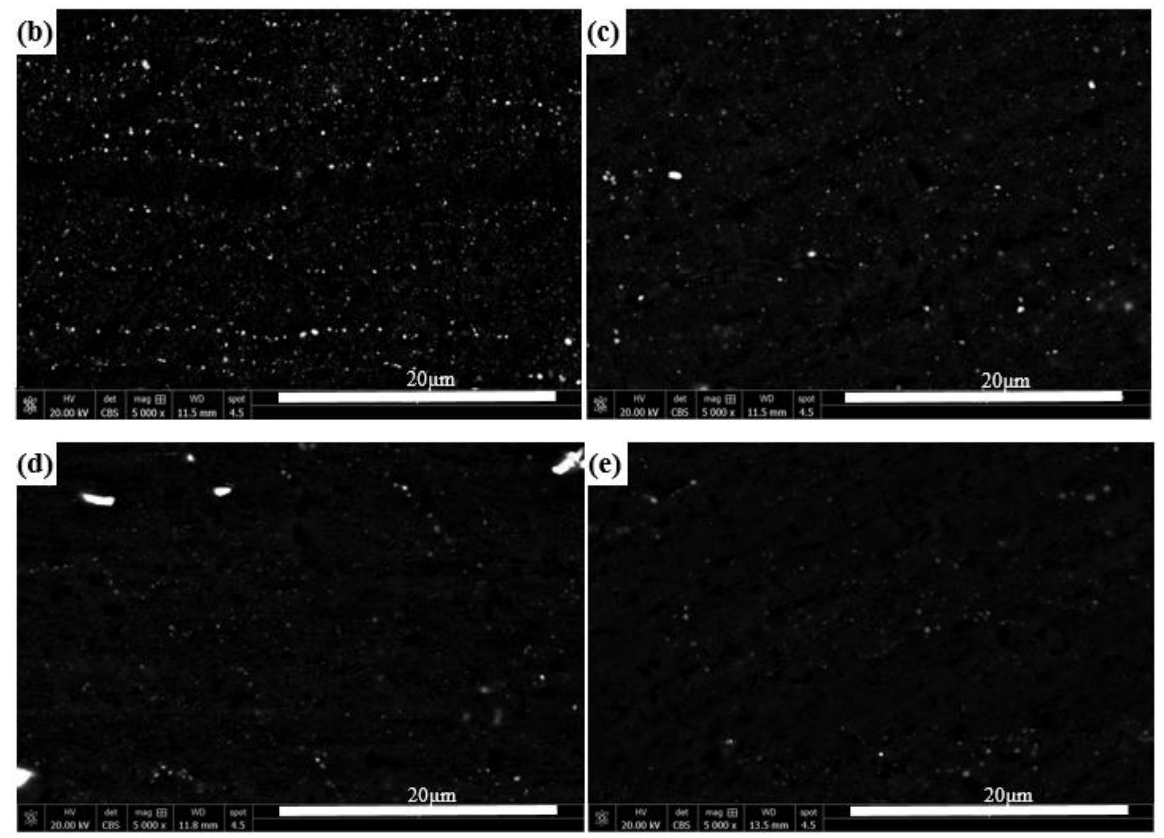

Figure 6. Scanning electron microscope (SEM) dark field image under (a) energy dispersive spectroscopy (EDS) analysis of T6 sample; (b) T6; (c) $200{ }^{\circ} \mathrm{C}$; (d) $300{ }^{\circ} \mathrm{C}$; (e) $400{ }^{\circ} \mathrm{C}$ under $50 \%$ compression.

Figure 7 shows bright-field TEM microstructures of the 6082-T6 and formed samples with $50 \%$ at three different temperatures. The undeformed T6 sample, as shown in Figure 7a, has a low dislocation density. The undeformed T6 sample had a large grain size, and no small grains and dislocation-formed subgrains were found. The other three groups of deformed samples shown in Figure $7 \mathrm{~b}-\mathrm{d}$ have introduced a large number of dislocations [12]. The grain boundary slipped due to deformation, and a large number of dislocations entanglements gradually formed fine sub-grains. This was particularly noticeable at $200{ }^{\circ} \mathrm{C}$. An increased heating temperature promotes dynamic recovery, leading to a gradual decrease in dislocation density [13].
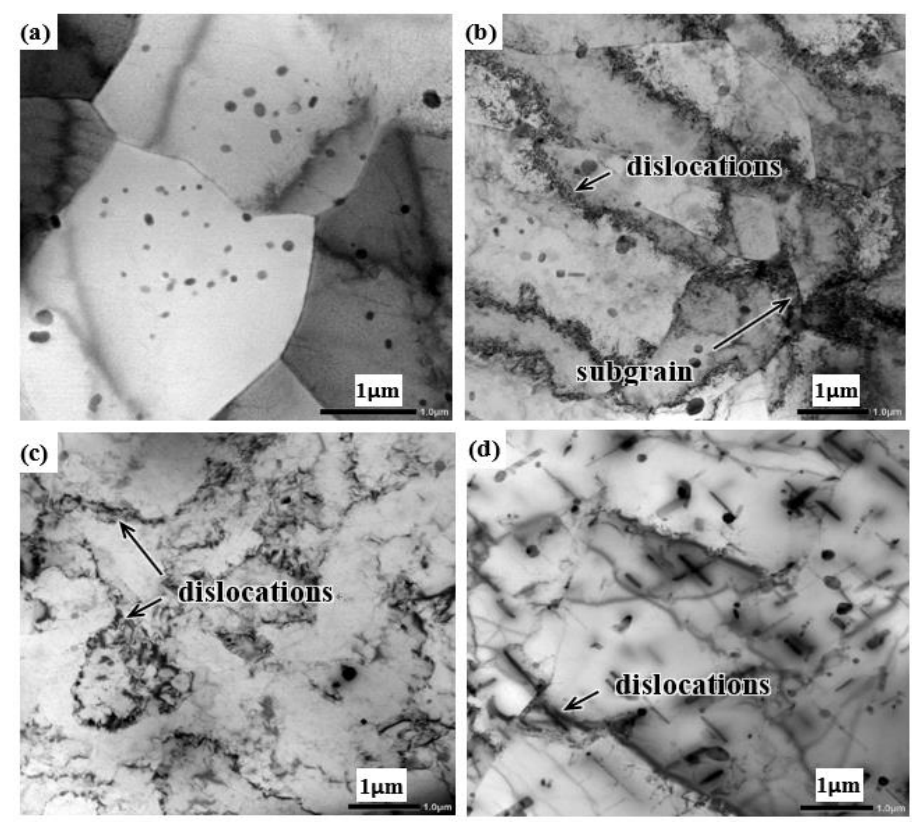

Figure 7. Transmission electron microscope (TEM) bright field of dislocations (a) T6; (b) $200{ }^{\circ} \mathrm{C}$; (c) $300{ }^{\circ} \mathrm{C}$; (d) $400{ }^{\circ} \mathrm{C}$ under $50 \%$ compression. 


\section{Discussion}

The use of $\mathrm{T} 6$ aluminum alloy to achieve rapid prototyping products can reduce the production process. When the heating temperature gradually increases from $200{ }^{\circ} \mathrm{C}$ to $400{ }^{\circ} \mathrm{C}$ during forming, the deformation resistance decreases with increasing temperature at the same compression degree (see Figure 2). High temperature promotes dynamic recovery and reduces dislocation density, thus reducing deformation resistance. The increased ductility of the metal at higher temperatures makes the material much easier to form. An analysis of the tensile curve from the compressed specimen shows that the higher the heating temperature during compression, the lower the tensile strength and longer true total elongation of the sample after compression, showing better ductility (Figure 3e). The experimental results show that the strength properties of the 6082-T6 material are considerably lowered when the heating temperature at the time of compression is higher than $300^{\circ} \mathrm{C}$. Therefore, to obtain a product with better performance, the heating temperature should be between $200^{\circ} \mathrm{C}$ and $300{ }^{\circ} \mathrm{C}$. It can be seen from the tensile stress-strain curve at $200{ }^{\circ} \mathrm{C}$ in Figure 2 that, compared with the T6 sample, in which the UTS is approximately $315 \mathrm{MPa}$, the minimum UTS appearing in the deformation degrees of $50 \%$ is also $280 \mathrm{MPa}$. All the samples formed at this temperature reach more than $80 \%$ of the T6 treatment.

The reasons for the differences in strength at the three experimental temperatures were investigated through microstructural observations. Fine grains have a strengthening effect. The strengthening effect can be expressed by the following equation: $\Delta \sigma_{\mathrm{y}}=\mathrm{k}_{\mathrm{y}} \mathrm{d}^{-1 / 2}[3,14]$ (d: average grain size, $\mathrm{ky}$ : Hall-Petchslope constant, ky value of high-strength aluminum alloy is usually $0.12 \mathrm{MPa} \mathrm{m}^{1 / 2}$ ). In this experiment, the grains are coarse because an extruded aluminum alloy is used. The average grain size is $80-100 \mu \mathrm{m}$ both before and after forming. This $\mathrm{k}_{\mathrm{y}}$ value indicates that $\Delta \sigma_{\mathrm{y}}$ approximates zero when the grain diameter $\mathrm{d}$ varies to micron scales. High temperatures reduces dislocation density, and small grains merge and grow. While compression deformation introduces dislocations, sub-grains appear $[15,16]$.

The mobility of the alloy is increased, which is manifested by an increase in elongation. Generally, small angle (ranging from $2^{\circ}$ to $15^{\circ}$ ) grain boundaries increase after compression, which means that subgrains and dislocation density increase. These microstructures have the ability to improve strength. The dislocation strengthening is generally described using $\Delta \sigma_{\text {dis }}=\alpha \operatorname{MGb} \rho^{1 / 2}[17,18]$ ( $\alpha$ : constant, $G$ : the shear modulus of pure aluminum, $b$ : the Burgers vector, $\rho$ : the dislocation density). As the temperature rises, the number of small-angle grain boundaries decreases, resulting in a decrease in grain slip resistance and a decrease in deformation resistance. The mechanical properties show that the higher the temperature during compression, the higher the elongation of the sample after deformation and the lower the strength.

In the undeformed T6 sample, there are a large number of fine precipitated phases arranged evenly, and the precipitated phase is needle-like with a diameter of a few nanometers or tens of nanometers. Figure $8 \mathrm{~b}$ shows a TEM micrograph of the precipitated phases of a sample heated at $200{ }^{\circ} \mathrm{C}$. The precipitated phase is still more evenly distributed, but is thicker in size than the T6 sample. The diameter is approximately $15-20 \mathrm{~nm}$. Figure $8 \mathrm{c}$, d show images of the precipitated phases at $300{ }^{\circ} \mathrm{C}$ and $400{ }^{\circ} \mathrm{C}$. The number of precipitated phases begins to decrease, and most of them are rod-shaped phases with diameters of approximately $30 \mathrm{~nm}$ and larger plate-like phases with diameters of approximately $100 \mathrm{~nm}$. Compared to $300{ }^{\circ} \mathrm{C}$, the precipitated phases at $400{ }^{\circ} \mathrm{C}$ are much larger in size and less distributed. Relevant literature shows in Table 1 [19] indicate that the phases in Figure 8a are mostly GP zones and $\beta^{\prime \prime}$ phase, and Figure $8 \mathrm{~b}$ is likely U1 and U2 phase due to the morphology. After compression at $300{ }^{\circ} \mathrm{C}$ and $400{ }^{\circ} \mathrm{C}$, the rod-like plates or cubes in Figure $8 \mathrm{c}, \mathrm{d}$ are regarded as $\beta^{\prime}$ and $\beta$ phases according to Table 1. 


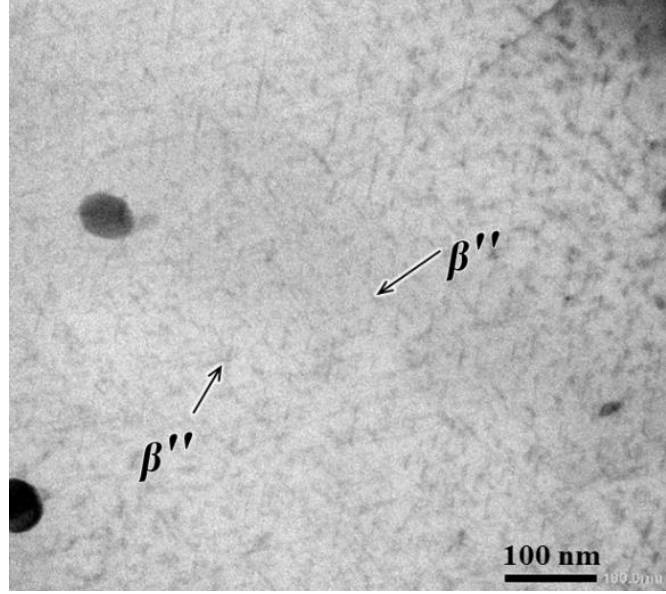

(a)

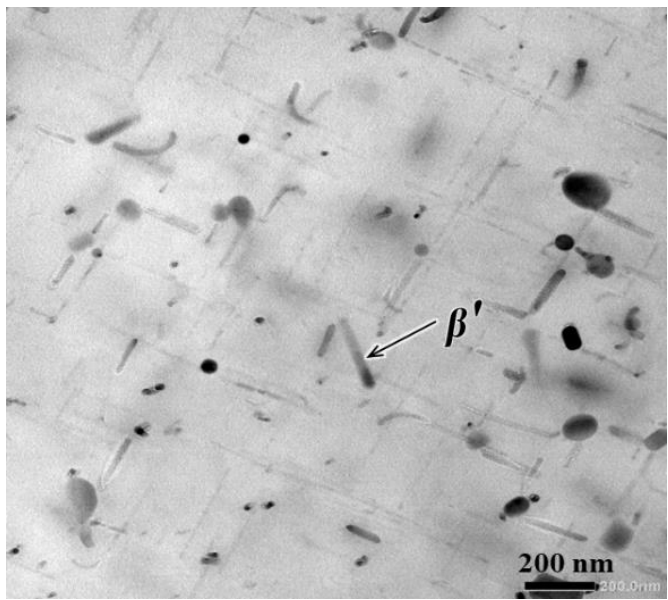

(c)

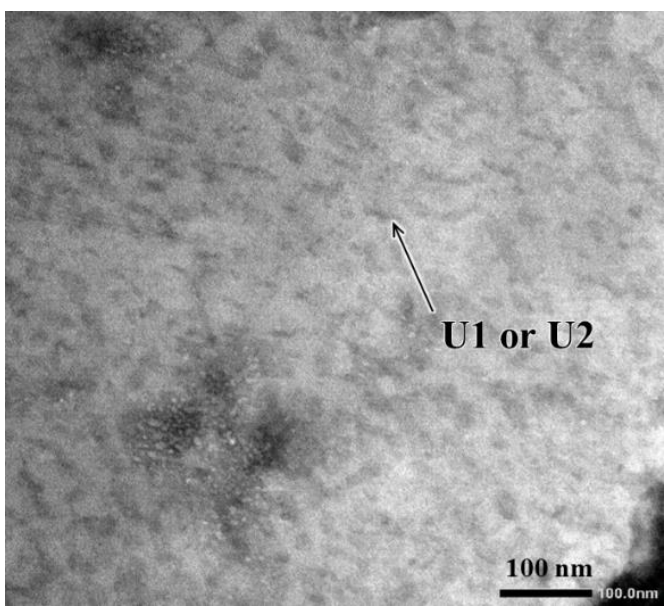

(b)

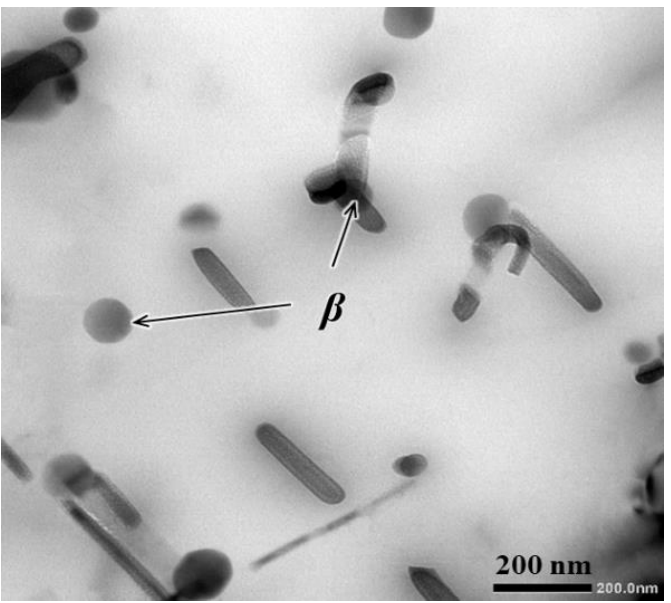

(d)

Figure 8. TEM morphology of precipitate phases (a) T6; (b) $200{ }^{\circ} \mathrm{C}$; (c) $300{ }^{\circ} \mathrm{C}$; (d) $400{ }^{\circ} \mathrm{C}$.

Table 1. Overview of observed precipitation phases in Al-Mg-Si alloy.

\begin{tabular}{ccc}
\hline Phase & Composition & Morphology \\
\hline GP [20] & $\mathrm{Mg}_{x} \mathrm{Al}_{5}-x \mathrm{Si}_{6}$ & Ranging from $1 \mathrm{~nm}$ to $3 \mathrm{~nm}$ spherical particles to needles of \\
$\beta^{\prime \prime}[21,22]$ & $\mathrm{Mg}_{5} \mathrm{Si}_{6}$ & $\sim 2 \mathrm{~nm} \times 2 \mathrm{~nm} \times 20 \mathrm{~nm}$ \\
$\mathrm{U} 1$ (type A) $[23]$ & $\mathrm{MgAl}_{2} \mathrm{SI}_{2}$ & Needles several hundred nanometers long, with $\sim 15 \mathrm{~nm}$ diameter \\
$\mathrm{U} 2$ (type B) [23,24] & $\mathrm{MgAlSi}^{\prime}$ & Needles several hundred nanometers long, with $\sim 15 \mathrm{~nm}$ diameter \\
$\beta^{\prime}[25,26]$ & $\mathrm{Mg}_{1.8} \mathrm{Si}$ & Rods several hundred nanometers long, with $\sim 10 \mathrm{~nm}$ diameter \\
$\beta[27]$ & $\mathrm{Mg}_{2} \mathrm{Si}$ & Plates or cubes cut-off size value: $\sim 80 \mathrm{~nm}$ \\
\hline
\end{tabular}

To further explore the effect of temperature on the change of the precipitated phase after deformation, EDS analysis (Figure 9) indicates the elemental composition after deformation at $400{ }^{\circ} \mathrm{C}$. Through the $\mathrm{Mg}$, Si distribution map, the enriched area corresponds to the rod-like and plate-like structures in the bright field image. Simultaneously, the two elements are evenly distributed in the field of view. The results show that some of the precipitated phases are significantly enlarged, and the other precipitated phases produced by T6 treatment are dissolved. Some round structures that contain Fe and Mn in the bright field image are dispersoids which usually form in the structure of 6082 aluminum alloys. These dispersoids has no strengthening effect. 

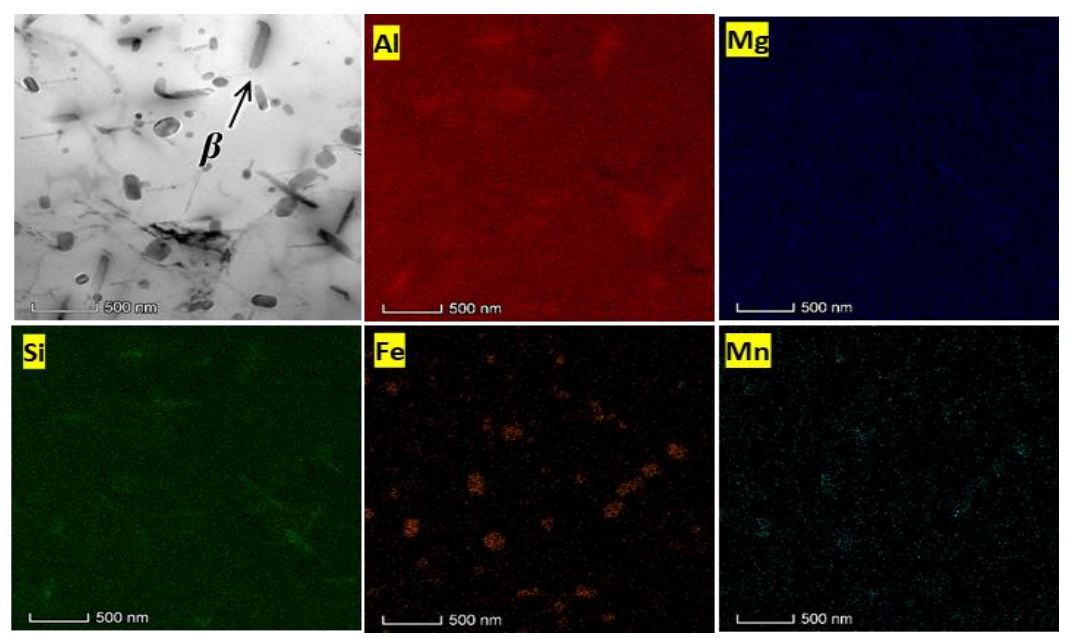

Figure 9. TEM precipitate morphology and element distribution maps at $400{ }^{\circ} \mathrm{C}$.

The main strengthening mechanism of aluminum alloys is precipitation phase strengthening [8,28-30]. As shown in Figure 3, in the dark field of SEM, the number of precipitated phases at three different temperatures is reduced compared with the T6 sample: The higher the temperature, the more the number decreases. The enhanced phase shape and distribution information are shown in Figure 7. The precipitate strengthening phase of the 6xxx series aluminum alloy is composed of $\mathrm{Al}, \mathrm{Mg}$, and $\mathrm{Si}$, which result from the following precipitation sequence: GP zone $\rightarrow \beta^{\prime \prime} \rightarrow \mathrm{U} 1 \rightarrow \mathrm{U} 2 \rightarrow \beta^{\prime} \rightarrow \beta$ phase [25]. The size also gradually increases. After T6 treatment, a large number of GP zones and $\beta^{\prime \prime}$ phases, which are well coherent with the Al matrix, are obtained. The strengthening effect is strongest, and the sample strength reaches the peak. After deformation at $200{ }^{\circ} \mathrm{C}$ (Figure $7 \mathrm{~b}$ ), the size of the precipitated phase is significantly coarser than that after T6 treatment, which is translated to the U1 and U2 phases, which also effectively strengthens the phase. Thus, the 6082-T6 aluminum alloy still has high strength after forming at this temperature. After deformation at $300^{\circ} \mathrm{C}$, the $\beta^{\prime \prime}$ phase of the sample (Figure 7c) grows significantly, and a rod-like $\beta^{\prime}$ phase and a plate-like $\beta$ phase with a large size appear. The semicoherent $\beta^{\prime}$ and the noncoherent $\beta$ substituted $\beta^{\prime \prime}$ phase with good coherence results in a significant decrease in strength. When the deformation temperature is increased to $400{ }^{\circ} \mathrm{C}$, the high temperature causes further growth of the precipitated phases and main phase present is the $\beta$ phase, which is not coherent with the Al matrix. Moreover, heating temperature of $400{ }^{\circ} \mathrm{C}$ causes the precipitation of dispersoids which main elements are $\mathrm{Fe}$ and $\mathrm{Mn}$, and $\beta^{\prime \prime}$ basically disappears in this sample. Under the macroscopic tensile test, the sample exhibits a lower strength according to the precipitation hardening mechanism $\Delta \sigma_{\mathrm{p}}=\mathrm{cf}^{1 / 2} \mathrm{r}^{-1}$ (f: volume fraction of precipitated phase. $r$ : radius of the precipitated phase, the unit is $\mu \mathrm{m}$. c: alloy constant) [31,32]. This result verifies that the increase of the radius for precipitation leads to a decrease in strengthening.

\section{Conclusions}

The compressive formability and microstructure evolution of 6082-T6 aluminum alloy have been investigated through different heating temperatures $\left(200{ }^{\circ} \mathrm{C}, 300^{\circ} \mathrm{C}\right.$, and $\left.400{ }^{\circ} \mathrm{C}\right)$ and deformation degrees $(30 \%, 50 \%$, and $70 \%)$. The following conclusions can be drawn:

(1) The experimental results indicate that after short-term heat preservation and compression deformation, the mechanical property of the alloy is more sensitive to heating temperature. The strength and elongation of the sample after compression deformation at a temperature of $200{ }^{\circ} \mathrm{C}$ is $301 \mathrm{MPa}$ and $11 \%$, respectively, which are close to the $6082-\mathrm{T} 6$ billet. When the temperature is increased to $300{ }^{\circ} \mathrm{C}$ and $400{ }^{\circ} \mathrm{C}$, the strength of the samples decreases significantly. 
(2) When the temperature is $200^{\circ} \mathrm{C}$, a large number of small-angle grain boundaries are produced, and the dislocation density increases significantly due to the compression deformation, leading to an increase in deformation resistance and strength. The needle-like $\beta^{\prime \prime}$ precipitated phase obtained by the original T6 treatment becomes larger, and the strengthening effect decreases. Therefore, the changes in these microstructures cause a slight decrease in strength compared with the T6 raw material. It is further noted that precipitated phase strengthening is the most important strengthening method for 6082 aluminum alloys.

(3) Under temperatures of $300{ }^{\circ} \mathrm{C}$ and $400{ }^{\circ} \mathrm{C}$, the compression deformation also induces a large amount of low angle grain boundaries and increased dislocation density, but less than that at a temperature of $200{ }^{\circ} \mathrm{C}$. Many precipitated phases are transferred from $\beta^{\prime \prime}$ to $\beta^{\prime}$ at $300{ }^{\circ} \mathrm{C}$, and a large amount of $\beta$ phase and dispersoids appear when the temperature is $400{ }^{\circ} \mathrm{C}$, leading to an obvious decrease in the strength of the samples. When the temperature is $200{ }^{\circ} \mathrm{C}$, good mechanical properties of the samples can be obtained during short heating and forming times.

Author Contributions: Conceptualization and methodology, Z.H.; investigation and resources, N.Z., H.M., Z.X.; writing-original draft preparation, Z.X.; writing-review and editing, Z.H., Z.X.; visualization and supervision, N.Z., Z.H.; project administration, Z.H. All authors have read and agreed to the published version of the manuscript.

Funding: This research was funded by the China Automobile Industry Innovation and Development Joint Fund grant number U1564202, the National Natural Science Foundation of China grant number 51775397, the 111 Project grant number B17034, Major Program of Science and Technology Program of Hubei Province grant number 2019AAA007, and the Innovative Research Team Development Program of the Ministry of Education of China grant number IRT17R83.

Conflicts of Interest: The authors declare no conflicts of interest.

\section{References}

1. Liu, J.T.; Zhang, Y.A.; Li, X.W.; Li, Z.H.; Xiong, B.Q.; Zhang, J.S. Phases and microstructures of high Zn-containing Al-Zn-Mg-Cu alloys. Rare Met. 2016, 35, 380-384. [CrossRef]

2. Chu, G.; Sun, L.; Wang, G.; Fan, Z.; Li, H. Axial hydro-forging sequence for variable-diameter tube of 6063 aluminum alloy. J. Mater. Process. Technol. 2019, 272, 87-99. [CrossRef]

3. Huo, W.; Hou, L.; Zhang, Y.; Zhang, J. Warm formability and post-forming microstructure property of high-strength AA 7075-T6 Al alloy. Mater. Sci. Eng. A 2016, 675, 44-54. [CrossRef]

4. El-Danaf, E.A.; Almajid, A.A.; Soliman, M.S. Hot deformation of AA6082-T4 aluminum alloy. J. Mater. Sci. 2008, 43, 6324-6330. [CrossRef]

5. Zhang, B.; Baker, T.N. Effect of the heat treatment on the hot deformation behaviour of AA6082 alloy. J. Mater. Process. Technol. 2004, 153, 153-154. [CrossRef]

6. Birol, Y.; Akdi, S. Cooling slope casting to produce EN AW 6082 forging stock for manufacture of suspension components. Trans. Nonferrous Met. Soc. China 2014, 24, 1674-1682. [CrossRef]

7. Birol, Y.; Emre, G.; Mehmet, A.G.; Seracettin, A. Processing of high strength EN AW 6082 forgings without a solution heat treatment. Mater. Sci. Eng. A 2016, 674, 25-32. [CrossRef]

8. Bouquerel, J.; Diawara, B.; Dubois, A.; Dubar, M.; Vogt, J.B.; Najjar, D. Investigations of the microstructural response to a cold forging process of the 6082-T6 alloy. Mater. Des. 2015, 68, 245-258. [CrossRef]

9. Garrett, R.P.; Lin, J.; Dean, T.A. An investigation of the effects of solution heat treatment on mechanical properties for AA 6xxx alloys: Experimentation and modelling. Int. J. Plast. 2005, 21, 1640-1657. [CrossRef]

10. Dadbakhsh, S.; Taheri, A.K.; Smith, C.W. Strengthening study on $6082 \mathrm{Al}$ alloy after combination of aging treatment and ECAP process. Mater. Sci. Eng. A 2010, 527, 4758-4766. [CrossRef]

11. Cabibbo, M. Microstructure strengthening mechanisms in different equal channel angular pressed aluminum alloys. Mater. Sci. Eng. A 2013, 560, 413-432. [CrossRef]

12. Wang, M.; Huang, L.P.; Liu, W.S.; Ma, Y.Z.; Huang, B.Y. Influence of cumulative strain on microstructure and mechanical properties of multi-directional forged 2A14 aluminum alloy. Mater. Sci. Eng. A 2016, 674, 40-51. [CrossRef]

13. Kocks, U.F.; Mecking, H. Physics and phenomenology of strain hardening: The FCC case. Prog. Mater. Sci. 2003, 48, 171-273. [CrossRef] 
14. Ma, K.; Wen, H.; Hu, T.; Topping, T.D.; Isheim, D.; Seidman, D.N.; Lavernia, E.J.; Schoenung, J.M. Mechanical behavior and strengthening mechanisms in ultrafine grain precipitation-strengthened aluminum alloy. Acta Mater. 2014, 62, 141-155. [CrossRef]

15. Hallberg, H.; Wallin, M.; Ristinmaa, M. Modeling of continuous dynamic recrystallization in commercial-purity aluminum. Mater. Sci. Eng. A 2010, 527, 1126-1134. [CrossRef]

16. Zhang, C.; Wang, C.; Guo, R.; Zhao, G.; Chen, L.; Sun, W.; Wang, X. Investigation of dynamic recrystallization and modeling of microstructure evolution of an $\mathrm{Al}-\mathrm{Mg}-\mathrm{Si}$ aluminum alloy during high-temperature deformation. J. Alloy. Compd. 2019, 773, 59-70. [CrossRef]

17. Starink, M.J.; Wang, P.; Sinclair, I.; Gregson, P.J. Microstructure and strengthening of Al-Li-Cu-Mg alloys and MMCs: II. Modelling of yield strength. Acta Mater. 1999, 47, 3855-3868. [CrossRef]

18. Lan, J.; Shen, X.; Liu, J.; Hua, L. Strengthening mechanisms of 2A14 aluminum alloy with cold deformation prior to artificial aging. Mater. Sci. Eng. A 2019, 745, 517-535. [CrossRef]

19. Ravi, C.; Wolverton, C. First-principles study of crystalstructure and stability of Al-Mg-Si (Cu) precipitates. Acta Mater. 2004, 529, 4213-4227. [CrossRef]

20. Marioara, C.D.; Andersen, S.J.; Jansen, J.; Zandbergen, H.W. Atomic model for GP-zones in a $6082 \mathrm{Al}-\mathrm{Mg}-\mathrm{Si}$ system. Acta Mater. 2001, 49, 321-328. [CrossRef]

21. Andersen, S.J.; Zandbergen, H.W.; Jansen, J. The crystal structure of the $\beta$ "phase in Al-Mg-Si Alloys. Acta Mater. 1998, 46, 3283-3298. [CrossRef]

22. Zandbergen, H.W. Structure determination of Mg5Si6 particles in Al by dymamic electron diffraction studies. Science 1997, 277, 1221-1225. [CrossRef]

23. Andersen, S.J.; Marioara, C.D.; Frøseth, A.; Vissers, R.; Zandbergen, H.W. Crystal structure of the orthorhombic U2-Al4Mg4Si4 precipitate in the Al-Mg-Si alloy system and its relation to the $\beta^{\prime}$ and $\beta^{\prime \prime}$ phases. Mater. Sci. Eng. A 2005, 390, 127-138. [CrossRef]

24. Abo Zeid, E.F.; Gaffar, M.A.; Gaber, A.; Mostafa, M.S. Correlative study of the thermoelectric power, electrical resistivity and different precipitates of Al-1.12 Mg-2 Si-0.35 Si (mass\%) alloy. J. Therm. Anal. Calorim. 2015, 122, 1269-1277. [CrossRef]

25. Cayron, C.; Buffat, P.A.; Buffat, P.A.; Cayron, C. Transmission electron microscopy study of the $\beta^{\prime}$ phase (Al-Mg-Si alloys) and QC phase (Al-Cu-Mg-Si alloys): Ordering mechanism and crystallographic structure. Acta Mater. 2000, 48, 2639-2653. [CrossRef]

26. Edwards, G.A.; Stiller, K.; Dunlop, G.L.; Couper, M.J. The precipitation sequence in Al-Mg-Si alloys. Acta Mater. 1998, 46, 3893-3904. [CrossRef]

27. Wu, Y.; Liao, H.; Lü, C. Dynamic precipitation and recrystallization in Al-12.5 wt $\% \mathrm{Si}-0.6 \mathrm{wt} \% \mathrm{Mg}-0.1 \mathrm{wt} \% \mathrm{Ti}$ alloy during hot-rolling and their impacts on mechanical properties. J. Alloy. Compd. 2019, 788, 125-135. [CrossRef]

28. Chen, J.H.; Costan, E.; Van Huis, M.A.; Xu, Q.; Zandbergen, H.W. Atomic Pillar-based nanoprecipitates strengthen AlMgSi alloys. Science 2006, 312, 416-419. [CrossRef]

29. Pang, Q.; Zhang, J.H.; Mohammad, J.H.; Hu, Z.L. Characterization of microstructure mechanical properties and formability for thermomechanical treatment of friction stir welded 2024-O alloys. Mater. Sci. Eng. A 2019, 765, 138303. [CrossRef]

30. Yan, L.Z.; Zhang, Y.A.; Xiong, B.Q.; Li, X.W.; Li, Z.H.; Liu, H.W.; Huang, S.H.; Zhao, G. Mechanical properties, microstructure and surface quality of $\mathrm{Al}-1.2 \mathrm{Mg}-0.6 \mathrm{Si}-0.2 \mathrm{Cu}$ alloy after solution heat treatment. Rare Met. 2017, 36, 550-555. [CrossRef]

31. Shercliff, H.R.; Ashby, M.F. A process model for age hardening of aluminium alloys-I. The model. Acta Metall. Mater. 1990, 38, 1789-1802. [CrossRef]

32. Gao, N.; Lu, D.H.; Zhao, Y.Y.; Liu, X.W.; Liu, G.H.; Wu, Y.; Liu, G.; Fan, Z.T.; Lu, Z.P.; George, E.P. Strengthening of a CrMnFeCoNi high-entropy alloy by carbide precipitation. J. Alloy. Compd. 2019, 792, 1028-1035. [CrossRef]

(C) 2020 by the authors. Licensee MDPI, Basel, Switzerland. This article is an open access article distributed under the terms and conditions of the Creative Commons Attribution (CC BY) license (http://creativecommons.org/licenses/by/4.0/). 